\title{
When governments spread lies, the fight is against two viruses: A study on the novel coronavirus pandemic in Brazil
}

\author{
Authors: \\ Priscila Biancovilli, (https://orcid.org/0000-0003-1425-4223) \\ Doctoral School of Health Sciences, University of Pécs, Pécs, Hungary. \\ Claudia Jurberg (http://orcid.org/0000-0003-3607-7299) $\mathrm{PhD}$ in Bioscience Education, \\ Management and Diffusion. Federal University of Rio de Janeiro and Oswaldo Cruz \\ Institute/Fiocruz, Rio de Janeiro, Brazil.
}

\section{Correspondence:}

Priscila Biancovilli

7621 Vörösmarty utca.4, Pécs, Hungary. E.mail biancovilli.priscila@etk.pte.hu

Conflicts of interest: The authors declare no conflict of interest

\begin{abstract}
Background: One of the challenges posed by the novel coronavirus pandemic is the infodemic risk, that is, a huge amount of information being published on the topic, along with misinformation and rumours. Around 100 million people in Brazil $(50 \%$ of the inhabitants) are users of social media networks, and a substantial amount of false information about the disease circulates in these media. Objectives: In this study, we examine the agenda-setting, media frame and content of misinformation published on the topic. Methods: We analysed all pieces of misinformation published by the Brazilian factchecking service "Agência Lupa", during six months of 2020. We used content analysis to classify the texts into categories, and three types of rumours were identified: Misleading content; fabricated content; false context. Results: We analysed 232 pieces of misinformation. Most were published on Facebook (76\%), followed by Whatsapp, with 10\% of total cases. Half of the stories (47\%) are classified as "real-life", that is, the focus is on everyday situations, or circumstances involving people. Regarding the type of misinformation, there is a preponderance of fabricated content, with 53\% of total, followed by false context (34\%) and misleading content (13\%). Wrong information was mostly published in text format (47\%). We discuss the influence that misinformation can have on the behaviour of the Brazilian population during the pandemic and how the media's agendasetting is influenced by false information published on social media. Conclusions: This study shows that misinformation about COVID-19 in Brazil seem to help establish an agenda-setting in the country, and the media frame is aligned with President Bolsonaro's political position.
\end{abstract}

Keywords: COVID-19, coronavirus, misinformation, social media, fake news, politics 
medRxiv preprint doi: https://doi.org/10.1101/2020.10.20.20215962; this version posted October 21, 2020. The copyright holder for this preprint (which was not certified by peer review) is the author/funder, who has granted medRxiv a license to display the preprint in It is made available under a CC-BY 4.0 International license.

\section{Introduction}

The novel coronavirus (SARS-CoV-2) pandemic generated an avalanche of information that circulates daily around the world. Throughout the first half of 2020, millions of people are or have been quarantined due to the pandemic and suffered negative psychological effects, including post-traumatic stress symptoms, confusion, and anger. Stressors included longer quarantine duration, infection fears, frustration, boredom, inadequate supplies, inadequate information, financial loss, and stigma (Brooks et al., 2020). The Internet is the easiest and fastest source to obtain health information in this context (Starbird et al., 2020). A public health crisis that involves numerous uncertainties requires precise information and answers for the adoption of appropriate behaviours and intelligent decision making (Jang \& Baek, 2019).

One of the challenges posed by this new coronavirus is the infodemic risk, that is, a tsunami of information about the topic that can also bring rumours and misinformation; with social media, this phenomenon is amplified, and it goes faster and further (Zarocostas, 2020). For this reason, it is important that the population is not only informed in real time but that information needs to be correct and updated, so as many people as possible can act properly to avoid spreading the disease.

The context of the study: the novel coronavirus pandemic in Brazil

The novel coronavirus in Brazil arrived in a scenario of a conservative, far-right government led by President Jair Bolsonaro, which systematically denies the severity of the SARS-CoV2 pandemic (Ajzenman et al., 2020). Because of this, the country's image in facing the pandemic was pointed out as deplorable (Craig, 2020). The attitude of the president and his ministers drew severe criticism from the international press (BBC News, 2020; Financial Times, 2020; The Economist, 2020). Moreover, the World Health Organization (WHO) (Lovelace Jr, 2020) also criticised Brazil's stance in controlling the pandemic, and for that reason the president threatened to pull Brazil out of the institution (Paraguaçu \& Brito, 2020).

The guidelines on wearing masks, social distancing, proper hand washing and the quarantine announced by the World Health Organization and endorsed by the Ministry of Health were routinely questioned by President Bolsonaro, who dismissed two medical ministers in the middle of the epidemic. After appointing a military officer to the post of Interim Minister of Health in May 2020 (Pinto, 2020) the Brazilian government caused, for some days, a 
medRxiv preprint doi: https://doi.org/10.1101/2020.10.20.20215962; this version posted October 21 , 2020. The copyright holder for this preprint (which was not certified by peer review) is the author/funder, who has granted medRxiv a license to display the preprint in It is made available under a CC-BY 4.0 International license.

blackout in the official data on morbidity and mortality (Leite et al., 2020, BBC News, 2020). Such omission caused a consortium of several broadcasting companies and volunteers to monitor the data daily (Bellini, 2020) in a country with 211 million inhabitants and 5,570 municipalities (IBGE, 2020). In addition to hiding pandemic data in the country, Bolsonaro has encouraged people to go out and even make appearances in stores, markets and public demonstrations on the streets (Ajzenman et al., 2020). As of October, 2020, Brazil had registered more than 5 million cases of the novel coronavirus (Worldometer, 2020a), being the country with the third highest number of cases in the world - the first is the United States and the second is India (Worldometer, 2020b).

In Brazil, about 100 million people are users of social networks (Statista, 2019). This number corresponds to almost half of the country's total population (IBGE, 2020). Online access to health information has been growing exponentially in the last few years. However, most of the information on the Internet is unregulated, and its quality remains questionable (Cuan-Baltazar et al., 2020).

\section{Definition and types of misinformation}

Misinformation on the Internet started to attract the attention of the media and academics during the U.S. elections in 2016; at that time, the expression "fake news" became increasingly popularised (Vos et al., 2019). Despite the extensive use of this term in the media and in scientific articles, it is considered inadequate to capture the complexity of the information disorder phenomenon (Lazer et al., 2018; Wang et al., 2019; Wardle, 2017). Fake news overlaps with other information disorders, such as misinformation (false, mistaken or misleading information) and disinformation (false information that is purposely spread to deceive or confuse people) (Fetzer, 2004; Lazer et al., 2018).

Even considering these differences, it is not always easy to fit a news item into one of the two categories, because we do not always know if the author of the news had the deliberate intention to deceive, or if he/she really believes in what is being written. For this reason, we follow the same classification as Wang (2019), which uses misinformation as an umbrella term that encompasses all types of false health information, unless the intention to deceive is evident.

The combination of infodemic brought about by the novel coronavirus disease situation, with the considerable presence of Brazilians on social networks, many of them without the full capacity to discern the quality of what is published, brings up a potential risk to public 
medRxiv preprint doi: https://doi.org/10.1101/2020.10.20.20215962; this version posted October 21 , 2020. The copyright holder for this preprint (which was not certified by peer review) is the author/funder, who has granted medRxiv a license to display the preprint in

It is made available under a CC-BY 4.0 International license.

health in the country (Uchoa, 2020). The deluge of conflicting information, misinformation and manipulated information on social media should be recognised as a global public health threat (Larson, 2018; Uchoa, 2020). The goal of this study is to analyse the misinformation distributed on social networks under the prism of intermedia agenda-setting theory (Vargo et al., 2018) and media frame theory (Entman, 1993), using Brazil as a case study.

\section{Intermedia agenda-setting theory and media frame theory}

The original agenda-setting theory (McCombs \& Shaw, 1972) was born from a fascinating idea that tries to explain how media plays an important part in shaping political reality. This theory resulted in a significant number of international studies on elections in different parts of the world, such as Argentina, United States, Taiwan, Singapore and Spain, just to name a few (Du, 2013). Over the years, the study of the agenda-setting over time went beyond the political spectrum and sought to understand how the media influences the public debate and the population's bias in relation to various themes. For example, if the media dedicates a lot of space in their coverage to talk about health, then the population will consider this issue to be of greater relevance. More recently, there are studies that focus on the fake news agendasetting: even if some audience members are aware that fake news is fake, the rise in coverage can generate an agenda-setting effect; there is also an interplay between different types of media outlets (traditional media, independent media, partisan media, social media users/influencers) in setting each other's news agenda (Vargo et al., 2018).

About 20 years after the first studies of the agenda-setting, the idea of the media frame was developed by Entman (1993). This term refers to the highlighted selection of certain aspects of reality by the media and, with this, establishes the problematic framing caused by the forms of interpretation, inducing collective thoughts (Entman, 1993). Thus, in addition to the agenda-setting, the media also somehow impose the bias of the news.

According to Entman (1993), there are four actors in this process: the communicator, who chooses what to say, consciously or unconsciously, according to his own experiences; the text, which presents an approach that is determined by keywords, stereotypes, sources of information and phrases that reinforce or not certain aspects of facts or judgments; the receiver, whose interpretations and conclusions are mixed with his experiences; and the culture, defined as the set of frames shared by a given social group.

Using the theoretical framework of intermedia agenda-setting and media frame, this study seeks to analyse how the misinformation disseminated in Brazil about the novel coronavirus 
medRxiv preprint doi: https://doi.org/10.1101/2020.10.20.20215962; this version posted October 21, 2020. The copyright holder for this preprint (which was not certified by peer review) is the author/funder, who has granted medRxiv a license to display the preprint in It is made available under a CC-BY 4.0 International license.

guides the discussions within society and affects health behaviours, influencing the progression of the pandemic in the country. To that end, we will try to answer the following questions:

RQ1: What are the prevalent types, frames and contents of misinformation in Brazil in relation to the pandemic in the novel coronavirus, and what are its main means and formats of dissemination on the Internet?

RQ2: Is the misinformation curve on social networks about the novel coronavirus in Brazil directly proportional to the increase in the number of cases in the country, reflecting the growing interest of the population on the topic as the virus spreads?

RQ3: In an extraordinary context such as the 2020 pandemic, does the misinformation agenda-setting mostly focus on the disease, or can we observe a heterogeneity of issues addressed?

\section{Methods}

This is a quali-quantitative exploratory study. We analysed all pieces of misinformation published by the Brazilian fact-checking service "Agência Lupa" (Lupa agency, in English) in the first 27 weeks (six months) of 2020 (from January 1, 2020 to July 4, 2020). Lupa agency was created in 2015 and is the first company specialised in fact-checking in Brazil; the checking is carried out by specialised journalists, based on successful processes implemented by fact-checking platforms such as the Argentine Chequeado and the North American Politifact (Equipe Lupa, 2015).

All news related to the novel coronavirus in the period was organised in an Excel table. For a news item to be considered as related to the topic, the fact-checking text should have at least once the terms "coronavirus" or "COVID-19". The following aspects of each news item were analysed: a) In what social media has it circulated?; b) What is the content classification and type of misinformation?; c) What is the type of media frame of the false information?; d) Are there recurrent themes in the sample studied?

\section{Misinformation, content and sentiment analysis of news stories}

The nomenclature developed by Wardle (2017) on the different types of misinformation inspired this data analysis. We used the following categories: a) Misleading content describes stories which are not entirely false but lead the reader to misinterpret the data; $b$ ) 
medRxiv preprint doi: https://doi.org/10.1101/2020.10.20.20215962; this version posted October 21 , 2020. The copyright holder for this preprint (which was not certified by peer review) is the author/funder, who has granted medRxiv a license to display the preprint in It is made available under a CC-BY 4.0 International license.

Fabricated content refers to $100 \%$ false pieces of information, with nothing that can be assessed as true; c) False context encompasses Wardle's categories of false context, false connection and manipulated content. The news was classified like this when headlines, visuals or captions do not support the content, or when genuine information (texts, photos or videos) are manipulated; d) Satire or parody refers to news that are not meant to be taken seriously, as the main motivation is comical. For this analysis, as in Sommariva et al. (2018) we decided not to include the category e) imposter content, when genuine sources are impersonated. This is because the analysis of misinformation producers is not within the scope of this study.

The content analysis of the texts was based on the methodology proposed by Laurence Bardin (1977), which is an inductive process. Firstly, two researchers read in depth (and independently) a sample of 20 news stories. Then, based on the readings, each researcher created a list of categories to describe them. Categorisation followed a semantic criterion: the news was separated according to the theme, and they could not be classified in more than one category. At the same time, the sentiment analysis of each text was also made. Sentiment analysis is the task of identifying positive and negative opinions, emotions, and evaluations (Wilson et al., 2005). Two researchers read all texts and identified the predominant sentiment (positive, negative or neutral) through document-level analysis (Shirsat et al., 2017). The task at this level is to determine the overall opinion of the document. Sentiment analysis at document level assumes that each document expresses opinions on a single entity (Behdenna et al., 2016).

Inter-coder reliability for content and sentiment analysis was $85 \%$. The same process and sample were used to classify the types of misinformation. In this case, inter-coder reliability was $80 \%$. Before classifying the full sample, the authors discussed their experiences and achieved consensus regarding inconsistencies. Then, one author coded the remaining messages.

\section{Results}

Content and media where misinformation was found

A total of 232 pieces of misinformation were analysed, starting from week 4 of 2020, when the first fact-checked story was published and finishing at week 27 of 2020. Regarding RQ1, we can see a prevalence of certain misinformation contents in Brazil, as shown in Figure 1. The stories were classified into seven content categories. Some categories are 
medRxiv preprint doi: https://doi.org/10.1101/2020.10.20.20215962; this version posted October 21,2020 . The copyright holder for this preprint (which was not certified by peer review) is the author/funder, who has granted medRxiv a license to display the preprint in perpetuity.

It is made available under a CC-BY 4.0 International license .

similar to other studies that analysed discourses in social networks (Biancovilli \& Jurberg, 2018; Picanço et al., 2018). We can observe that almost half of the stories (47\%) are classified as "real-life", that is, the focus is on everyday situations, or situations involving people.

The second most frequent category is "politics". Here are the stories that focus on politicians, governments, parties, political decisions, aid from governments, laws, decrees, or messages of adulation/adoration aimed at a politician, and they represent $23 \%$ of the total amount of registered news. In third place is information on advances in "science and epidemiological data" (14\%). Pieces of misinformation related to virtual scams, conspiracy theories and warnings (any kind of warning about what to do or not to do during the pandemic) account for $10 \%$ of the total, followed by "health tips" $(6 \%)$.

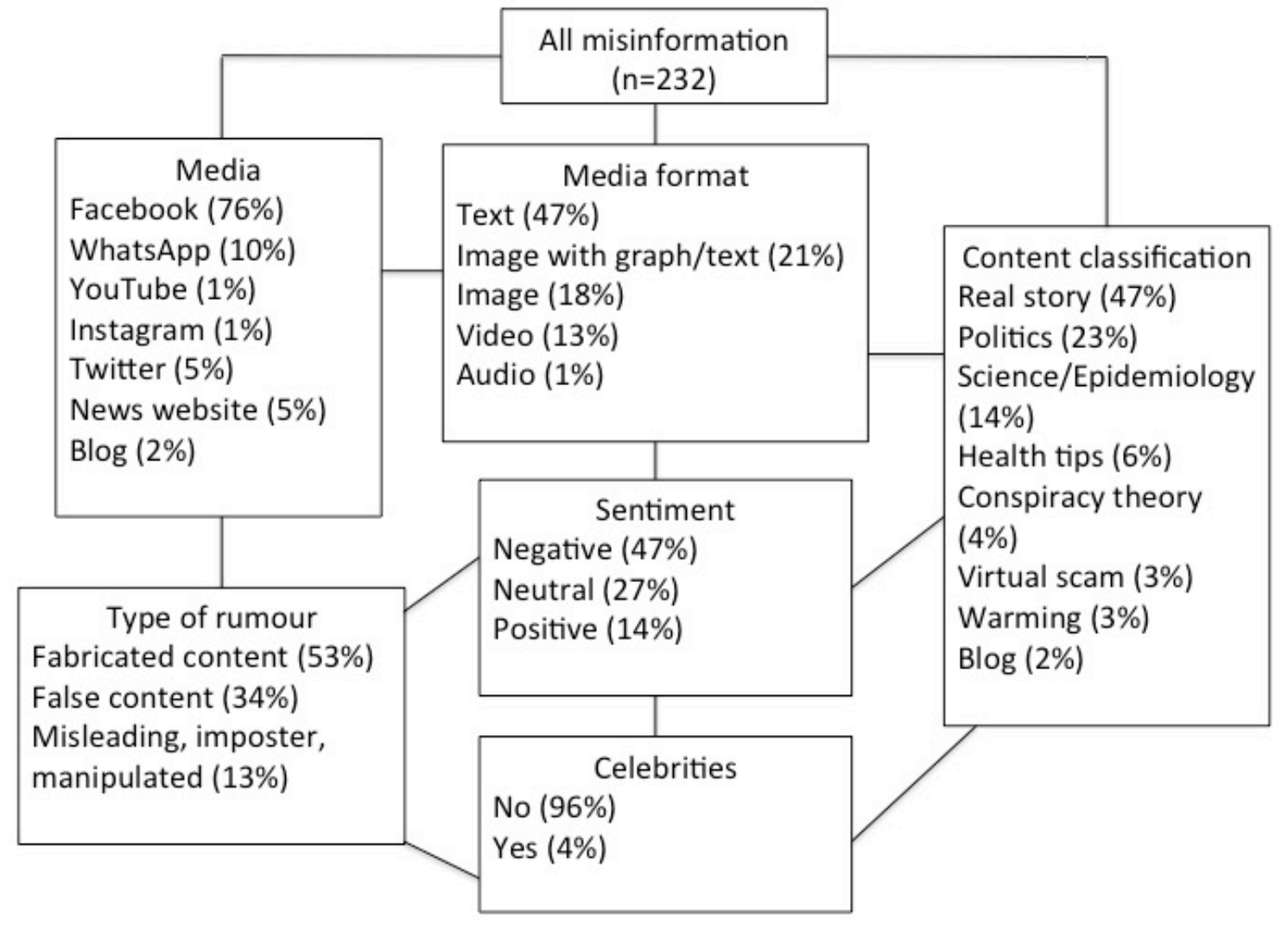

Figure 1. Types and classification of misinformation about COVID-19 in Brazil, between January 1, 2020 and July 4, 2020.

Still regarding RQ1, most pieces of misinformation were published on Facebook $(76 \%)$, followed by WhatsApp, with $10 \%$ of total cases (see Figure 1). This data sample does not correspond to the ranking of the most used social media platforms in Brazil. According to a 
medRxiv preprint doi: https://doi.org/10.1101/2020.10.20.20215962; this version posted October 21, 2020. The copyright holder for this preprint (which was not certified by peer review) is the author/funder, who has granted medRxiv a license to display the preprint in It is made available under a CC-BY 4.0 International license.

recent survey conducted on the habits of Brazilians on social networks (We are Social, 2020), YouTube is the most accessed social media page (96\% of Internet users aged 16 to 64 reported using this platform in December 2019); in second place is Facebook (90\%), and in third place is WhatsApp (88\%), followed by Instagram (79\%), Facebook Messenger $(66 \%)$ and Twitter (48\%).

We also observed that the most prominent type of rumour was "fabricated content" (53\%), followed by "false content" (34\%). It is important to note that all misinformation published on news websites and blogs was also posted on Facebook. When the news appears simultaneously on Facebook and a blog or on Facebook and a news website, it means that there is a link in the Facebook post leading to an external page. In such cases, Facebook serves as a call for the reader to see the full story at the indicated link. In this way, we conclude that $100 \%$ of the fact-checked content was published on at least one social network.

Although YouTube is the most popular social media by Internet users in Brazil, only three pieces of misinformation about COVID-19 were found there during this period. Moreover, Instagram and Telegram do not seem to be popular social networks for the spread of misinformation, as only $1 \%$ of the total sample was found there.

It is interesting to note that the negative sentiment became predominant throughout the course of the epidemic in Brazil and was mainly associated with "real-life stories" and "politics". Almost 50\% of the information with a negative frame was concentrated on these two themes. Another curious fact was the low use (10/232 or $4 \%)$ of celebrities to disseminate false information.

\section{Misinformation about COVID-19 over time and compared to other topics}

Concerning RQ2, the first news item recognised by Lupa agency as false in Brazil dates to January 24, 2020 (week 4 of the year). In this week, only one piece of misinformation went through the fact-check process. The peak of fact-checked news occurred in week 14, when 24 pieces of misinformation were published. Figures 2 and 3 compare the number of diagnosed coronavirus cases per week with the number of pieces of misinformation detected by Lupa agency in the same period. We can see that there is no parallelism between the two phenomena. 
medRxiv preprint doi: https://doi.org/10.1101/2020.10.20.20215962; this version posted October 21, 2020. The copyright holder for this preprint (which was not certified by peer review) is the author/funder, who has granted medRxiv a license to display the preprint in It is made available under a CC-BY 4.0 International license .

Figure 2. Number of fact-checked misinformation items detected by Lupa agency, since the first case recognised on February 26, 2020 (week 9) until the week 27, in July 4,2020

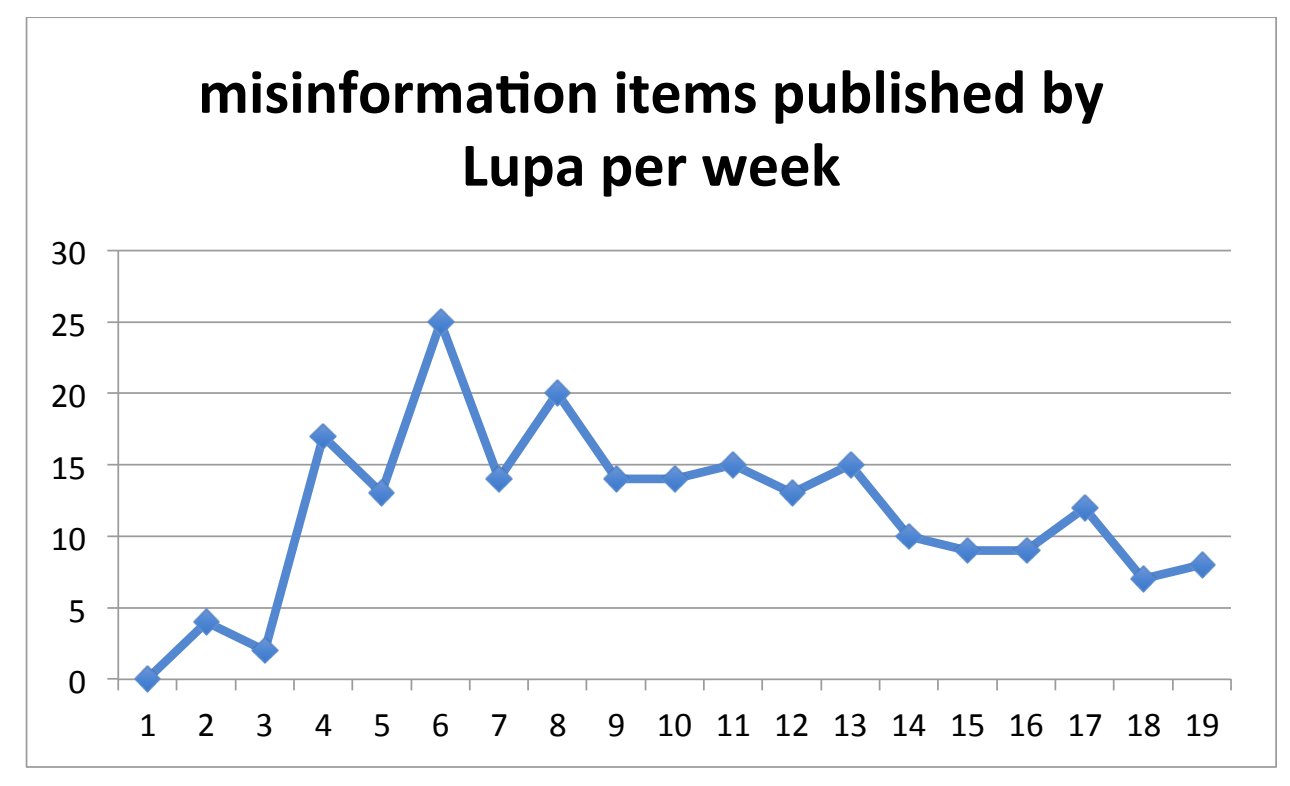

Figure 3. Number of new diagnosed coronavirus cases per week in the same period.

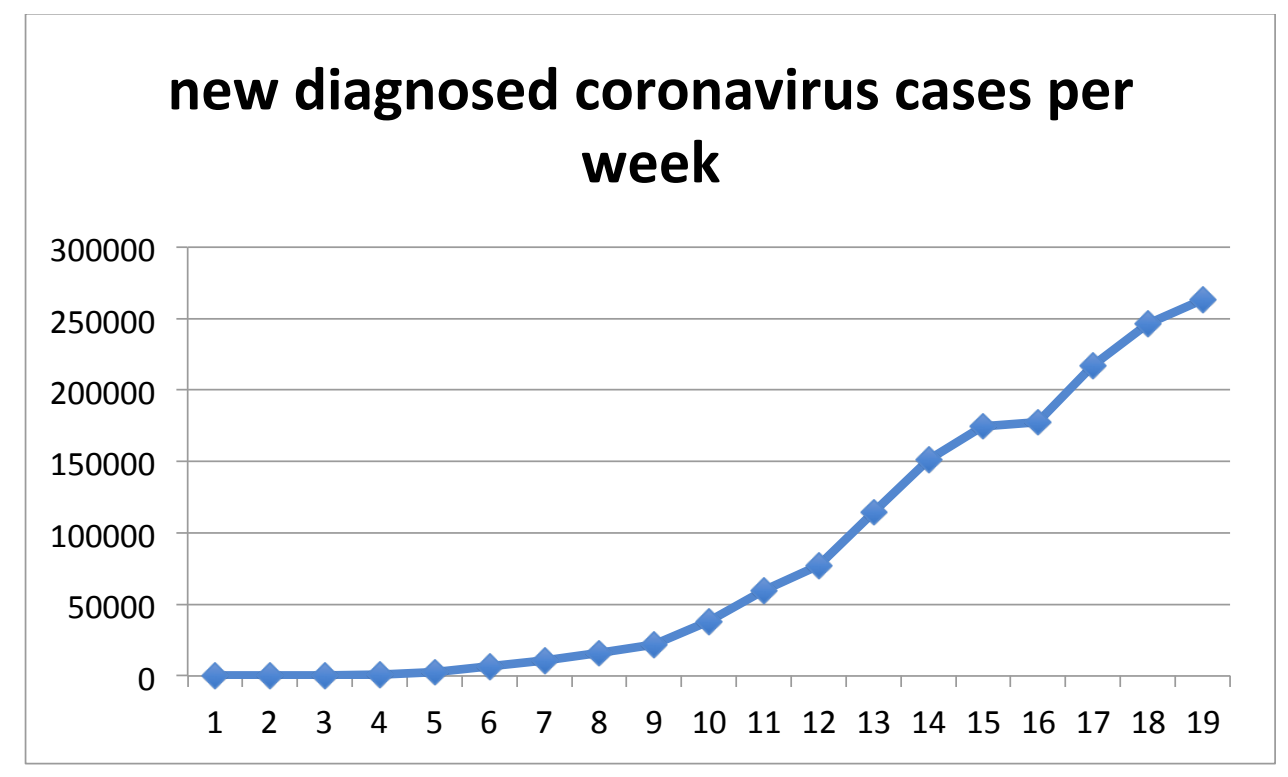

Agenda-setting of misinformation in a pandemic

Regarding RQ3, we noticed that until week 11, the fact-checked content was mostly unrelated to the novel coronavirus. From week 12 onwards, there is a turning point, and in subsequent weeks this issue becomes central to the misinformation agenda-setting. However, in weeks 23 and 26, most of the news items that passed through Lupa agency are not related to the pandemic of the novel coronavirus. Therefore, the misinformation agenda 
medRxiv preprint doi: https://doi.org/10.1101/2020.10.20.20215962; this version posted October 21, 2020. The copyright holder for this preprint (which was not certified by peer review) is the author/funder, who has granted medRxiv a license to display the preprint in perpetuity.

It is made available under a CC-BY 4.0 International license .

in emergency health situations is not always focused only on the topic. It is important to mention that at the beginning of week 23 (May 31, 2020), there was a series of protests in some cities in Brazil in favour of democracy and against the government of Jair Bolsonaro (Phillips, 2020). For this reason, many false news stories were produced with a focus on demoralising the image of the participants in these protests.

Figure 4. Number of pieces of misinformation that were checked by Lupa agency every week, separated between topics related to COVID-19 and others.

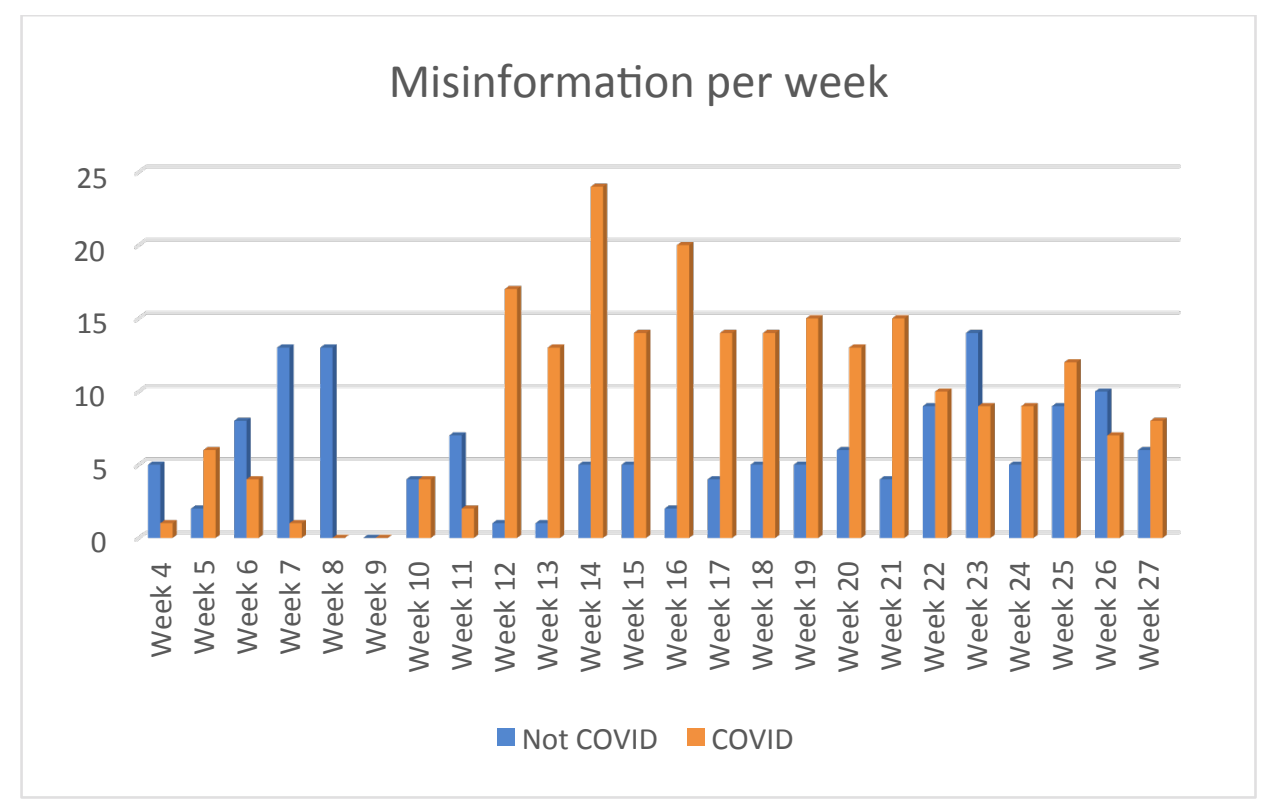

\section{Discussion}

This study explored the spread of misinformation on COVID-19 in Brazil through social media, analysing the stories published by the fact-checking service Lupa agency from January 1, 2020 to July 4, 2020. Although at the end of our sample the pandemic has not yet ended, this study aims to understand the flow of misinformation produced in the first half of 2020 and the agenda-setting, the topics addressed in the country and how the media framing may reflect the positions of social actors and politicians that are relevant in Brazilian society at this time. Brazil is one of the countries that had an exponential increase in the disease case curve during the first half of 2020, and there is not enough literature to try to explain the influence of misinformation on social networks as one of the factors for this problem.

We can see that $100 \%$ of the pieces of misinformation in our sample were published on social networks. Even those on blogs and news websites were also posted (via hyperlink) on 
medRxiv preprint doi: https://doi.org/10.1101/2020.10.20.20215962; this version posted October 21, 2020. The copyright holder for this preprint (which was not certified by peer review) is the author/funder, who has granted medRxiv a license to display the preprint in It is made available under a CC-BY 4.0 International license.

Facebook, which demonstrates the strength of these new media in spreading information. Social media play a vital role during crises, serving as both a first-hand information channel on the scene as well as a supplementary channel offering specific information demanded by people directly involved in the crisis (Jang \& Baek, 2019).

To continue answering RQ3, we can observe that most news detected as misinformation in Brazil (n=232) had COVID-19 or novel coronavirus as its main theme, in comparison to news related to other topics $(\mathbf{n}=\mathbf{1 4 3})$. During a pandemic, this type of misinformation can have serious consequences for the population. Mistaken health tips or false scientific and epidemiological data can make people believe that the disease is not so serious, or that a few simple actions (such as drinking tea or gargling) are enough to prevent COVID-19. A study conducted in Northeastern Brazil with 2,259 respondents (Lima et al., 2020) showed that some beliefs of the interviewees are similar to the government speeches denying the seriousness of the pandemic. For the group aged 80 and over, the pandemic in Brazil would be less severe than in many countries; Brazilians would have superior virus protection to people in other countries; and the warm climate of the Northeast of the country would favor the reduction of the pandemic in the region. As this disease is extremely contagious (Kooraki et al., 2020), a less concerned behaviour of the population in relation to it can cause a loosening in measures of social distancing, which contributes to the faster spread of the virus (CDC, 2020) and the overwhelming of hospitals (Powell, 2020).

When we analyse the misinformation agenda-setting in our sample, we observe the attempt to establish some specific themes within society. The themes classified as "real-life stories" and "politics" were the most prevalent in the period. Within these topics, three subjects drew attention: a) Field hospitals supposedly being empty, which proves that the disease is not real $(\mathbf{n}=14)$; b) People cured by chloroquine and hydroxychloroquine ( $\mathbf{n = 1 3})$; c) Burial of empty coffins as if they were patients killed by the virus $(\mathbf{n}=7)$.

The discussion about supposedly empty hospitals gained prominence when the curve of cases of the disease in Brazil began to accelerate, in April 2020 (BBC News, 2020a). Some of the misinformation shows people filming or taking pictures of hospitals with empty receptions. What happens is that many of the hospitals receive only patients referred from other health units, which is why they do not perform emergency care. There are also videos that are contextually false, stating that there are many empty hospital beds, when in fact these videos are old or were filmed in other hospitals in smaller cities. In an official speech 
medRxiv preprint doi: https://doi.org/10.1101/2020.10.20.20215962; this version posted October 21 , 2020. The copyright holder for this preprint (which was not certified by peer review) is the author/funder, who has granted medRxiv a license to display the preprint in

It is made available under a CC-BY 4.0 International license.

after the disclosure of these false news item, Bolsonaro asked supporters to enter hospitals to film whether beds are really occupied (Jucá et al., 2020), which goes against the guidance of doctors due to the risk of contagion. In fact, some of his followers followed his request and invaded hospitals with patients hospitalised for the novel coronavirus, speaking loudly and disrespecting the medical team (Ribeiro, 2020). In addition, in a survey of 833 university students in the health field (Brito Aragao et al., 2020), they stated that the main source of information on COVID-19 was government websites (88.7\%), followed by other health institutions (57.3\%). That is, despite the government's denial of the seriousness of the epidemic, official sources remained the most sought after, shaping the agenda setting (McCombs \& Shaw, 1972, Vargo et al. 2018) and the media frame (Entman, 1993) of Brazilian news during the pandemic.

Regarding the news involving coffins, one of the pieces of misinformation that most caught the public's attention was one that said that "coffins of victims of COVID-19 in Belo Horizonte were full of stones". Another report states that "pits were opened to bury empty coffins in Marabá”. Such misinformation gained prominence on social networks and became a subject in society. For this reason, families began to gather to open sealed coffins with victims of COVID-19, to check if the body they were about to bury was really their family member (Boechat, 2020). In one case, five people were infected due to this action (Pitombo, 2020).

In our sample, 13 of the 232 pieces of misinformation address chloroquine or hydroxychloroquine. All stories treat these drugs as a cure for COVID-19, some with testimonies from celebrities (Tom Hanks's wife) or anonymous people, and others condemning politicians for not believing in the power of those medicines. Mr. Bolsonaro defended the use of chloroquine against COVID-19 in a pronouncement broadcast on national television in April 2020 (Ricard \& Medeiros, 2020). Although there is some evidence about the effectiveness of this substance, data from high-quality clinical trials are still urgently needed (Cortegiani et al., 2020). Another study suggests that high dosage of chloroquine is not recommended for severely ill patients, because of its potential safety hazards (Borba et al., 2020). Due to the sensational and uncontrolled promotion of hydroxychloroquine and chloroquine for the treatment of COVID-19, clinical trials with other more promising drugs and therapies are being pushed aside, because patients refuse to accept them (Ledford, 2020). In other Latin American countries, such as Dominican Republic, clients without a prescription purchase these drugs, as there is a culture of self- 
medRxiv preprint doi: https://doi.org/10.1101/2020.10.20.20215962; this version posted October 21,2020 . The copyright holder for this preprint (which was not certified by peer review) is the author/funder, who has granted medRxiv a license to display the preprint in It is made available under a CC-BY 4.0 International license.

medication and lack of governmental regulation on drug use (Tapia, 2020). This same culture exists in all regions of Brazil.

Misinformation propagated in Brazil during the coronavirus pandemic seems to help to establish the agenda-setting in the country, shaping public debates and society's behaviour (even after fact-checking). The simple fact that journalists dedicate part of their time to address and correct false information, not only at Lupa agency but also in other media, already makes the subject more widespread and, therefore, more debated. A network analysis has found that the sites targeted with the most inbound hyperlinks from fake news networks were mainstream media, social networking sites, and Wikipedia. Few of the targeted sites linked back to the fake news sites (Vargo et al., 2018).

The predominant media frame in misinformation is negationist and endorsed by President Bolsonaro's speeches, encouraging disrespectful, dangerous and even bizarre behaviour by part of the population. The very fact that the president ignores health recommendations for the pandemic sets a dangerous precedent, causing part of the population to do the same and thus increasing the contagion curve and the number of preventable deaths (Reeves, 2020). Although in the beginning of the pandemic, in March, Brazilians largely adhered to the rules of social isolation and quarantine, over time many people ignored the danger posed by the disease and returned to live their lives normally — even with a growing number of cases and deaths throughout the country (BBC News, 2020c). In June 2020, commerce in the main Brazilian cities reopened; shopping, restaurants and stores started to function normally, and crowds of thousands of unconcerned people in bars were reported by the media (Pedroso et al., 2020; Weir, 2020)

The actions of a political leader are essential to coordinate, organise and ensure that the rules are obeyed by citizens. In a pandemic, the need for a leader who recognises the seriousness of the problem and takes quick action is even greater. A study conducted during the pandemic (Ajzenman et al., 2020) showed that the social distancing measures taken by citizens in pro-government localities weakened compared to places where political support of the president is less strong; they also found evidence that this is stronger in municipalities with a larger proportion of Evangelical parishioners, a key group in terms of support for the president.

Another study that analysed the information disseminated by public health officials during the MERS (Middle East respiratory syndrome) outbreak in South Korea found that less 
medRxiv preprint doi: https://doi.org/10.1101/2020.10.20.20215962; this version posted October 21,2020 . The copyright holder for this preprint (which was not certified by peer review) is the author/funder, who has granted medRxiv a license to display the preprint in

It is made available under a CC-BY 4.0 International license.

credible information from those professionals led to more frequent use of online news and social media for acquiring information related to the disease. Even though our study did not collect data on the frequency of use of social networks during the pandemic in Brazil, we can observe that there is a relationship between the agenda-setting and the media frame of Brazilian misinformation and the low adherence of the population to preventive care - all this supported by President Bolsonaro's irresponsible actions. That is, if the country's leader is not concerned with the severity of the disease, firing two ministers of health in the middle of the pandemic and insisting on chloroquine as a miracle solution, part of the population that supports him feels more confident to return to normality (BBC News, 2020b; Financial Times, 2020; The Economist, 2020). To corroborate this idea, a Brazilian study (Garcia, 2020; Roubaud et al., in press) shows a correlation between the preference for President Jair Bolsonaro and the expansion of COVID-19 in certain regions of the country. According to the survey, for every 10 percentage points more votes for Bolsonaro, there is an increase of $11 \%$ in the number of cases and $12 \%$ in the number of deaths. The researchers characterize the situation as the "Bolsonaro effect" in the spread of the new coronavirus pandemic in Brazil. Other Brazilian studies also reinforce this correlation, showing that whenever the president minimized the pandemic, the rate of social isolation decreases and more people became infected and died (Garcia, 2020).

The guidelines of WHO leaders emphasise the importance of a broad and coherent response from Brazil, especially from governments (at the federal, state or municipal level), to control the pandemic (Ponce, 2020). The lack of a unified response makes the population confused, facilitating denialist attitudes, and neglecting individual actions to protect against the disease.

It is not a coincidence that the misinformation found in this study is similar to the presidential speech. In 2019, an investigation called the "Parliamentary Commission of Inquiry of Fake News" started in the Brazilian Congress, created to investigate the suspected use of false news and misinformation during Jair Bolsonaro's presidential campaign in 2018. Comprised of 15 senators and 15 deputies, this investigation began with a 180-day period to investigate the creation of false profiles and cyber-attacks on various social networks, with possible influence on the electoral process and public debate (Harris, 2020; Phillips, 2020). In April 2020, the commission was extended and gained another 180 days, which are used to investigate who are the creators and disseminators of disinformation 
medRxiv preprint doi: https://doi.org/10.1101/2020.10.20.20215962; this version posted October 21,2020 . The copyright holder for this preprint (which was not certified by peer review) is the author/funder, who has granted medRxiv a license to display the preprint in It is made available under a CC-BY 4.0 International license.

related to the novel coronavirus. There is a strong suspicion that Bolsonaro and his allies (known as the "office of hate") are participating in schemes for creating false profiles and bots to propagate misinformation against political opponents and contradicting the health measures recommended by the World Health Organization (McCoy, 2020). In July 2020, Facebook has complied with an order by Brazil's Supreme Court to block the accounts of a dozen top allies of far-right President Jair Bolsonaro (BBC News, 2020d). In other words, the dis- or misinformation agenda-setting and media frame on COVID-19 would not only be endorsed by the president and his allies but also created by them.

\section{Conclusions and limitations}

This study shows that misinformation about COVID-19 in Brazil seem to help establish an agenda-setting in the country, and the media frame is aligned with President Bolsonaro's political position.

In face of all the challenges discussed in this article, the Brazilian media and science communicators must understand the main characteristics of misinformation in social media about COVID-19, so that they can develop evidence-based content that helps to increase health literacy and modulate the perception of risk. Health educators must have a massive presence in the most popular social media sites with attractive and up-to-date content, as an effort to counteract the spread of misinformation.

As a limitation of our study, we were unable to measure the public engagement of factchecked stories, to get a more accurate idea of how many people were directly affected by the misinformation. In addition, we have no way of controlling how many people had access to or shared the pieces of misinformation circulating on WhatsApp, due to the private nature of their groups and the lack of data on engagement in this social network. Another limitation is the fact that we used the news verified by Lupa agency only as the basis for this research. As the amount of news circulating about the pandemic is enormous, we have no way of knowing whether the news verified in this period represents the entire sample of misinformation shared in Brazil. Despite these limitations, we believe that this work can offer help so that scientists, journalists and health educators understand the characteristics of the misinformation health agenda-setting during the pandemic and are better able to counter this problem.

\section{Acknowledgments}


medRxiv preprint doi: https://doi.org/10.1101/2020.10.20.20215962; this version posted October 21, 2020. The copyright holder for this preprint (which was not certified by peer review) is the author/funder, who has granted medRxiv a license to display the preprint in It is made available under a CC-BY 4.0 International license.

This study was supported by the (Brazilian) National Council for Scientific and

Technological Development (Conselho Nacional de Desenvolvimento Científico e Tecnológico), and Carlos Chagas Filho Foundation (Fundação Carlos

Chagas Filho de Amparo à Pesquisa do Estado do Rio de Janeiro). We would also like to acknowledge Lilian Thomer for developing statistical and mathematical analysis and Mariza Tavares for her insights on misinformation in Brazil.

\section{References}

Ajzenman, N., Cavalcanti, T., \& Da Mata, D. (2020). More than words: Leaders' speech and risky behavior during a pandemic. https://www.inet.econ.cam.ac.uk/research-papers/wp$\underline{\text { abstracts }}$

Bardin, L. (1977). L'analyse de contenu. Presses universitaires de France.

BBC News. (2020a, April 11). Brazil reports more than 1,000 coronavirus deaths. BBC News. https://www.bbc.com/news/world-latin-america-52251342

BBC News. (2020b, June 7). Coronavirus: Hard-hit Brazil removes data amid rising death toll. https://www.bbc.com/news/world-latin-america-52952686

BBC News. (2020c, June 22). Coronavirus: Brazil becomes second country to pass 50,000 deaths—BBC News. https://www.bbc.com/news/world-latin-america-53132225

Behdenna, S., Barigou, F., \& Belalem, G. (2016). Sentiment analysis at document level. In A. Unal, M. Nayak, D. K. Mishra, D. Singh, \& A. Joshi (Eds.), Smart trends in information technology and computer communications (pp. 159-168). Springer.

https://doi.org/10.1007/978-981-10-3433-6_20 
medRxiv preprint doi: https://doi.org/10.1101/2020.10.20.20215962; this version posted October 21, 2020. The copyright holder for this preprint (which was not certified by peer review) is the author/funder, who has granted medRxiv a license to display the preprint in It is made available under a CC-BY 4.0 International license .

Bellini, P. (2020, July 13). Brazil's government hid the data for Covid-19. Then volunteer developers got to work. Rest of World. https://restofworld.org/2020/brazil-datatransparency-covid19/

Biancovilli, P., \& Jurberg, C. (2018). How to optimize health messages about cancer on facebook: Mixed-methods study. JMIR Cancer, 4(2), e11073. https://doi.org/10.2196/11073

Boechat, Y. (2020, April 29). Famílias abrem caixões lacrados à beira das covas coletivas para ter certeza de que estão enterrando seus parentes em Manaus.

https://br.noticias.yahoo.com/familias-abrem-caixoes-a-beira-das-covas-coletivas-para-tercerteza-de-que-estao-enterrando-seus-parentes-em-manaus-161006292.html

Borba, M. G. S., Val, F. F. A., Sampaio, V. S., Alexandre, M. A. A., Melo, G. C., Brito, M., Mourão, M. P. G., Brito-Sousa, J. D., Baía-da-Silva, D., Guerra, M. V. F., Hajjar, L. A., Pinto, R. C., Balieiro, A. A. S., Pacheco, A. G. F., Santos, J. D. O., Naveca, F. G., Xavier, M. S., Siqueira, A. M., Schwarzbold, A., ... for the CloroCovid-19 Team. (2020). Effect of high vs low doses of chloroquine diphosphate as adjunctive therapy for patients hospitalized with severe acute respiratory syndrome coronavirus 2 (SARS-CoV-2) infection: A randomized clinical trial. JAMA Network Open, 3(4), e208857. https://doi.org/10.1001/jamanetworkopen.2020.8857

Brito Aragao, M. G., Fernandes Gomes, F. I., Siqueira Silva Coelho, C., Pinho Maia Paixao de Melo, L., \& Milori Corona, S. A. (2020). Where do Brazilian dental students seek information about COVID-19? [Preprint]. Dentistry and Oral Medicine. https://doi.org/10.1101/2020.08.24.20179614

Brooks, S. K., Webster, R. K., Smith, L. E., Woodland, L., Wessely, S., Greenberg, N., \& Rubin, G. J. (2020). The psychological impact of quarantine and how to reduce it: Rapid review of 
medRxiv preprint doi: https://doi.org/10.1101/2020.10.20.20215962; this version posted October 21 , 2020. The copyright holder for this preprint (which was not certified by peer review) is the author/funder, who has granted medRxiv a license to display the preprint in

It is made available under a CC-BY 4.0 International license.

the evidence. The Lancet, 395(10227), 912-920. https://doi.org/10.1016/S0140$\underline{6736(20) 30460-8}$

CDC. (2020, February 11). Coronavirus Disease 2019 (COVID-19). Centers for Disease Control and Prevention. https://www.cdc.gov/coronavirus/2019-ncov/prevent-getting-sick/socialdistancing.html

Cortegiani, A., Ingoglia, G., Ippolito, M., Giarratano, A., \& Einav, S. (2020). A systematic review on the efficacy and safety of chloroquine for the treatment of COVID-19. Journal of Critical Care, 57, 279-283. https://doi.org/10.1016/j.jcrc.2020.03.005

Craig, D. (2020). Pandemic and its metaphors: Sontag revisited in the COVID-19 era. European Journal of Cultural Studies, 136754942093840. https://doi.org/10.1177/1367549420938403

Cuan-Baltazar, J. Y., Muñoz-Perez, M. J., Robledo-Vega, C., Pérez-Zepeda, M. F., \& Soto-Vega, E. (2020). Misinformation of COVID-19 on the Internet: Infodemiology Study. JMIR Public Health and Surveillance, 6(2), e18444. https://doi.org/10.2196/18444

Du, Y. R. (2013). Intermedia agenda-setting in the age of globalization: A multinational agendasetting test. Global Media and Communication, 9(1), 19-36. https://doi.org/10.1177/1742766512463038

Entman, R. M. (1993). Framing: Toward clarification of a fractured paradigm. Journal of Communication, 43(4), 51-58. https://doi.org/10.1111/j.1460-2466.1993.tb01304.x

Equipe Lupa. (2015, October 15). [Agência Lupa] O que é a Agência Lupa? Agência Lupa. https://piaui.folha.uol.com.br/lupa/2015/10/15/como-selecionamos-as-frases-que-seraochecadas/

Fetzer, J. H. (2004). Information: Does it have to be true? Minds and Machines, 14(2), 223-229. https://doi.org/10.1023/B:MIND.0000021682.61365.56 
medRxiv preprint doi: https://doi.org/10.1101/2020.10.20.20215962; this version posted October 21 , 2020. The copyright holder for this preprint (which was not certified by peer review) is the author/funder, who has granted medRxiv a license to display the preprint in

It is made available under a CC-BY 4.0 International license.

Financial Times. (2020). Bolsonaro defies coronavirus to rally against Congress.

https://www.ft.com/content/79fe5d26-621f-11ea-b3f3-fe4680ea68b5

Garcia, D. (2020, October 12). "Efeito Bolsonaro” sobre alta nos casos de coronavírus surpreende pesquisadores. Folha de S.Paulo.

https://www1.folha.uol.com.br/mercado/2020/10/efeito-bolsonaro-sobre-alta-nos-casos-decoronavirus-surpreende-pesquisadores.shtml

Harris, B. (2020, July 13). Spread of fake news adds to Brazil's pandemic crisis. https://www.ft.com/content/ea62950e-89c0-4b8b-b458-05c90a55b81f

IBGE. (2020). Projeção da população. https://www.ibge.gov.br/apps/populacao/projecao/box_popclock.php

Islam, M. S., Sarkar, T., Khan, S. H., Mostofa Kamal, A.-H., Hasan, S. M. M., Kabir, A., Yeasmin, D., Islam, M. A., Amin Chowdhury, K. I., Anwar, K. S., Chughtai, A. A., \& Seale, H. (2020). COVID-19-related infodemic and Its impact on public health: A global social media analysis. The American Journal of Tropical Medicine and Hygiene, 103(4), 1621-1629. https://doi.org/10.4269/ajtmh.20-0812

Jang, K., \& Baek, Y. M. (2019). When information from public health officials is untrustworthy: The use of online news, Interpersonal networks, and social media during the MERS outbreak in South Korea. Health Communication, 34(9), 991-998. https://doi.org/10.1080/10410236.2018.1449552

Jucá, J., Pedroso, R., \& Picheta, R. (2020, June 15). Bolsonaro tells Brazilians to inspect hospitals themselves, investigations ensue. $\mathrm{CNN}$.

https://edition.cnn.com/2020/06/15/americas/brazil-bolsonaro-coronavirus-hospitalinvestigation-intl/index.html 
medRxiv preprint doi: https://doi.org/10.1101/2020.10.20.20215962; this version posted October 21, 2020. The copyright holder for this preprint (which was not certified by peer review) is the author/funder, who has granted medRxiv a license to display the preprint in It is made available under a CC-BY 4.0 International license .

Kooraki, S., Hosseiny, M., Myers, L., \& Gholamrezanezhad, A. (2020). Coronavirus (COVID19) outbreak: what the department of radiology should know. Journal of the American College of Radiology, 17(4), 447-451. https://doi.org/10.1016/j.jacr.2020.02.008

Larson, H. J. (2018). The biggest pandemic risk? Viral misinformation. Nature, 562(7727), 309309. https://doi.org/10.1038/d41586-018-07034-4

Lazer, D. M. J., Baum, M. A., Benkler, Y., Berinsky, A. J., Greenhill, K. M., Menczer, F., Metzger, M. J., Nyhan, B., Pennycook, G., Rothschild, D., Schudson, M., Sloman, S. A., Sunstein, C. R., Thorson, E. A., Watts, D. J., \& Zittrain, J. L. (2018). The science of fake news. Science, 359(6380), 1094-1096. https://doi.org/10.1126/science.aao2998

Ledford, H. (2020). Chloroquine hype is derailing the search for coronavirus treatments. Nature, 580(7805), 573-573. https://doi.org/10.1038/d41586-020-01165-3

Leite, J., Travaglini, F., \& Preissler Iglesias, S. (2020, June 7). Brazil's Covid data blackout is a tragedy, ex-health chief says_Bloomberg. https://www.bloomberg.com/news/articles/2020$\underline{\text { 06-07/brazil-s-covid-data-blackout-is-a-tragedy-ex-health-chief-says }}$

Lima, D. L. F., Dias, A. A., Rabelo, R. S., Cruz, I. D. da, Costa, S. C., Nigri, F. M. N., \& Neri, J. R. (2020). COVID-19 no estado do Ceará, Brasil: Comportamentos e crenças na chegada da pandemia. Ciência \& Saúde Coletiva, 25(5), 1575-1586. https://doi.org/10.1590/1413$\underline{81232020255.07192020}$

Lovelace Jr, B. (2020, July 13). WHO says U.S. and Brazil accounted for half of new daily coronavirus cases: "Too many countries are headed in the wrong direction." CNBC. https://www.cnbc.com/2020/07/13/who-says-us-and-brazil-accounted-for-half-of-newdaily-coronavirus-cases.html 
medRxiv preprint doi: https://doi.org/10.1101/2020.10.20.20215962; this version posted October 21 , 2020. The copyright holder for this preprint (which was not certified by peer review) is the author/funder, who has granted medRxiv a license to display the preprint in It is made available under a CC-BY 4.0 International license.

McCombs, M. E., \& Shaw, D. L. (1972). The Agenda-Setting function of mass media. Public Opinion Quarterly, 36(2), 176. https://doi.org/10.1086/267990

Paraguaçu, L., \& Brito, R. (2020, June 6). Bolsonaro threatens WHO exit as COVID-19 kills “a Brazilian per minute.” Reuters. https://www.reuters.com/article/us-health-coronavirusbrazil-idUSKBN23C1TF

Pedroso, R., Reverdosa, M., \& Darlington, S. (2020, July 3). Brazil coronavirus: Rio reopens as experts warn worst is yet to come-CNN.

https://edition.cnn.com/2020/07/02/americas/brazil-coronavirus-restaurants-riointl/index.html

Phillips, T. (2020, May 27). Brazil police target key Bolsonaro supporters in fake news raids. The Guardian. http://www.theguardian.com/world/2020/may/27/brazil-fake-news-networkraids-bolsonaro

Picanço, L., Biancovilli, P., \& Jurberg, C. (2018). Beyond the drama: The beautiful life in news feeds on cancer. Journal of Cancer Education, 33(2), 424-428. https://doi.org/10.1007/s13187-016-1094-2

Pinto, A. E. de S. (2020, May 19). In WHO speech, interim minister of Health omits the seriousness of Brazil's Crisis. Folha de S.Paulo.

https://www1.folha.uol.com.br/internacional/en/scienceandhealth/2020/05/in-who-speechinterim-minister-of-health-omits-the-seriousness-of-brazils-crisis.shtml

Pitombo, J. P. (2020, May 13). Família abre caixão em velório e cinco são contaminados por Covid-19 na Bahia-13/05/2020_Cotidiano-Folha.

https://www1.folha.uol.com.br/cotidiano/2020/05/familia-abre-caixao-em-velorio-e-cinco$\underline{\text { sao-contaminados-por-covid-19-na-bahia.shtml }}$ 
medRxiv preprint doi: https://doi.org/10.1101/2020.10.20.20215962; this version posted October 21 , 2020. The copyright holder for this preprint (which was not certified by peer review) is the author/funder, who has granted medRxiv a license to display the preprint in It is made available under a CC-BY 4.0 International license.

Ponce, D. (2020). The impact of coronavirus in Brazil: Politics and the pandemic. Nature Reviews Nephrology, 1-1. https://doi.org/10.1038/s41581-020-0327-0

Powell, A. (2020, March 27). On-again, off-again looks to be best social-distancing option. Harvard Gazette. https://news.harvard.edu/gazette/story/2020/03/how-to-preventoverwhelming-hospitals-and-build-immunity/

Reeves, P. (2020, July 27). Brazil's Bolsonaro is accused of crime against humanity over coronavirus “Neglect.” NPR.Org. https://www.npr.org/sections/coronavirus-liveupdates/2020/07/27/895940087/brazils-bolsonaro-is-accused-of-crime-against-humanityover-coronavirus-neglect

Ribeiro, G. (2020, June 5). São Paulo: Lawmakers invade field hospital. The Brazilian Report. https://brazilian.report/coronavirus-brazil-live-blog/2020/06/05/sao-paulo-pro-bolsonarolawmakers-invade-field-hospital/

Ricard, J., \& Medeiros, J. (2020). Using misinformation as a Political Weapon:Covid-19 and Bolsonaro In Brazil. Harvard Kennedy School Misinformation Review. https://doi.org/10.37016/mr-2020-013

Roubaud, F., Saboia, J., Castilho Reis, M., Razafindrakoto, M., \& Pero, V. (n.d.). The municipios facing COVID-19 in Brazil: Socioeconomic vulnerabilities, transmisssion mechanisms and public policies. Instituto de Economia da UFRJ in press .

Shirsat, V. S., Jagdale, R. S., \& Deshmukh, S. N. (2017). Document level sentiment analysis from news articles. 2017 International Conference on Computing, Communication, Control and Automation (ICCUBEA), 1-4. https://doi.org/10.1109/ICCUBEA.2017.8463638

Sommariva, S., Vamos, C., Mantzarlis, A., Đào, L. U.-L., \& Martinez Tyson, D. (2018). Spreading the (Fake) News: Exploring health messages on social media and the implications 
medRxiv preprint doi: https://doi.org/10.1101/2020.10.20.20215962; this version posted October 21 , 2020. The copyright holder for this preprint (which was not certified by peer review) is the author/funder, who has granted medRxiv a license to display the preprint in It is made available under a CC-BY 4.0 International license.

for health professionals using a case study. American Journal of Health Education, 49(4), 246-255. https://doi.org/10.1080/19325037.2018.1473178

Starbird, K., Arif, A., \& Wilson, T. (2019). Disinformation as collaborative work: Surfacing the participatory nature of strategic information operations. Proceedings of the ACM on HumanComputer Interaction, 3(CSCW), 1-26. https://doi.org/10.1145/3359229

Statista. (2019). Brazil: Number of social network users 2019. https://www.statista.com/statistics/278408/number-of-social-network-users-in-brazil/

Tapia, L. (2020). COVID-19 and fake news in the Dominican Republic. The American Journal of Tropical Medicine and Hygiene, 102(6), 1172-1174. https://doi.org/10.4269/ajtmh.20-0234

The Economist. (2020, March 26). Brazil's president fiddles as a pandemic looms.

https://www.economist.com/the-americas/2020/03/26/brazils-president-fiddles-as-apandemic-looms

Uchoa, P. (2020, May 20). Brazil coronavirus: 'Our biggest problem is fake news'-BBC News. https://www.bbc.com/news/world-latin-america-52739734

Vargo, C. J., Guo, L., \& Amazeen, M. A. (2018). The agenda-setting power of fake news: A big data analysis of the online media landscape from 2014 to 2016. New Media \& Society, 20(5), 2028-2049. https://doi.org/10.1177/1461444817712086

Vos, T. P., Hanusch, F., Dimitrakopoulou, D., Geertsema-Sligh, M., \& Sehl, A. (Eds.). (2019). The International Encyclopedia of Journalism Studies (1st ed.). Wiley. https://doi.org/10.1002/9781118841570

Wang, Y., McKee, M., Torbica, A., \& Stuckler, D. (2019). Systematic literature review on the spread of health-related misinformation on social media. Social Science \& Medicine, 240, 112552. https://doi.org/10.1016/j.socscimed.2019.112552 
medRxiv preprint doi: https://doi.org/10.1101/2020.10.20.20215962; this version posted October 21, 2020. The copyright holder for this preprint (which was not certified by peer review) is the author/funder, who has granted medRxiv a license to display the preprint in It is made available under a CC-BY 4.0 International license .

Wardle, C. (2017, February 16). Fake news. It's complicated. Medium. https://medium.com/1stdraft/fake-news-its-complicated-d0f773766c79

Weir, B. (2020, July 7). Brazil opens itself up, to everything except masks—CNN. CNN.

https://edition.cnn.com/2020/07/06/americas/brazil-coronavirus-sao-pauloreopens/index.html

Wilson, T., Wiebe, J., \& Hoffmann, P. (2005). Recognizing contextual polarity in phrase-level sentiment analysis. Proceedings of the Conference on Human Language Technology and Empirical Methods in Natural Language Processing - HLT '05, 347-354.

https://doi.org/10.3115/1220575.1220619

Worldometer. (2020a, October 15). Brazil Coronavirus.

https://www.worldometers.info/coronavirus/country/brazil/

Worldometer. (2020b, October 15). Coronavirus countries.

https://www.worldometers.info/coronavirus/\#countries

Zarocostas, J. (2020). How to fight an infodemic. The Lancet, 395(10225), 676.

https://doi.org/10.1016/S0140-6736(20)30461-X 